\title{
TEN YEARS AFTER ETHNIC CONFLICT IN SOUTHERN KYRGYZSTAN: SOCIO-ECONOMIC CAUSES AND EFFECTS
}

\begin{abstract}
In June 2010, a fierce ethnic conflict erupted in southern Kyrgyzstan, causing heavy casualties and property damage. The ethnic conflict occurred for both historical reasons and realistic backgrounds, especially the policy mistakes of the interim government. This article analyses the causes and effects of this ethnic conflict based on relevant information and reports that have been disclosed by international media. This ethnic conflict not only caused a huge negative impact on the social stability of Kyrgyzstan, but also worsened the security situation in Central Asia. At present, with the national conflict as a lesson, the governments of Kyrgyzstan and Uzbekistan are working hard to improve the relationship between the two countries and the two major ethnic groups.
\end{abstract}

\section{Key words:}

Kyrgyzstan; Uzbekistan; ethnic conflicts; Osh Initiative.

(C) Zhang Yuyan, 2020.

Yuyan Zhang, PhD, Lecturer, School of Politics and International Relations, Institute for Central Asian Studies, Lanzhou University, China. Email: zhangyuyan04@126.com. 
JEL: F51, F52.

2020 is the tenth anniversary of the ethnic conflict in southern Kyrgyzstan. During the ten years, Kyrgyzstan officials and various independent and international organizations have published more than 10 investigation reports (Human Rights Watch 2010, International Crisis Group 2010, Osh Initiative 2011, Ferghana News Agency 2011, Freedom House 2012). However, there are different opinions on the process and cause of the incident, and there are different versions of the number of casualties and property losses, which has caused considerable difficulties in the analysis of the incident. According to the investigation reports from international media, the author uses a comparative research method to analyse the causes and effects of the ethnic conflict in the south of Kyrgyzstan, with a view to reflecting on this ethnic conflict on the tenth anniversary.

\section{Overview of ethnic conflicts in southern Kyrgyzstan}

On April 6, 2010, the so-called «People's Revolution» (this is Kyrgyzstan's most commonly used official name for the «April Incident») was launched by the opposition in Bishkek, the capital of Kyrgyzstan. Police and interior forces opened fire on the marchers, killing 77 people in Bishkek (Sputnik news 2015) and causing casualties in other cities. At the same time, the government arrested multiple opposition leaders and the opposition gathered more people to confront the government. The opposition occupied the government building. Some law enforcement agencies stopped working and changed to plain clothes. Robbery and arson were committed, and the opposition burned Bakiyev's residence. Later, the opposition established an interim government headed by Otunbayeva and declared complete control over the government. On the evening of the 8th, President Bakiyev was forced to flee the south. On the evening of the 15th, Bakiyev flew from Jalalabad to the southern city of Taraz, Kazakhstan. On the 16th, Bakiyev was forced to announce resignation.

When people thought that the situation in Kyrgyzstan settled, on June 11, a serious conflict between the Kyrgyz and Uzbek ethnic groups broke out in Osh (second capital), Osh and Jalalabad Regions in the south of the country. The conflict occurred more intensely in the morning of June 11 to June 12, which was 
not long, but then it lasted for more than a week. There were different opinions about the cause of the incident, among which the the credible statement was given by Human Rights Watch (2010, pp. 3-4): «It first started in a club in the centre of Osh, triggered by fighting among Kyrgyz and Uzbek youths involved in gambling, and quickly spread to Osh and some other cities in the south».

After the incident, the international community and the Kyrgyzstan's people strongly demanded to investigate the truth behind the incident and bring the perpetrators to justice. On July 12, Roza Otunbayeva, the interim President, issued a decree calling for a national investigation for reasons, effects and advice on the "June Incident». The National Commission on the tragic events was then established. Its members included sociologists, politicians, experts from law and security, human rights institutions in Kyrgyzstan, representatives of the media and socio-cultural organizations. They visited the site of the conflict in southern Kyrgyzstan twice to conduct field investigations and obtain evidence. Visits were also made to the heads of the central government and local self-government authorities, representatives of the intelligence and security agencies, educational institutions, health institutions and media representatives of Osh, Jalalabad and those two regions. The Commission also met with other relevant international organizations (UNHCR, EU, Amnesty International and others) and exchanged opinions. Finally, the Commission released "Conclusions of the National Commission on the tragic events that occurred in the south of the republic in June 2010" in January 2011. In addition, civilian activists from the Kyrgyz and Uzbek ethnic groups established an independent investigative group «Osh Initiative» in Tashkent of Uzbekistan in October 2010. According to their findings, «Report on the Results of an Independent Public Investigation on June (2010) Events in Kyrgyzstan» was published in January 2011. The statements on the «June Incident» are quite different in these two reports. Based on the comprehensive reference of these two reports, the author will analyse the causes and effects of «June Incident».

\section{Reasons for the outbreak of ethnic conflict in southern Kyrgyzstan}

The ethnic conflict in southern Kyrgyzstan is the most serious ethnic conflict that has occurred in the almost 30 years since the country attained its independence. The reasons for its spread are quite complicated. They include both historical ethnic grievances, the influence of the former Soviet Union's ethnic policies, and the real factors, such as the conflict between Kyrgyzstan and Uzbekistan, the involvement of organized criminal groups and extremists, and the mistakes of the interim government. It should be noted that although the "June incident» manifested as an ethnic conflict between the Kyrgyz and Uzbek ethnic 
groups, the ethnic conflict is not the principal contradiction in this incident. The deep-rooted reason is also the impact of the long-standing social conflicts within Kyrgyzstan and conflicts between the Kyrgyzstan and Uzbekistan. The involvement of local extremists and organized criminal groups greatly deteriorated local ethnic relations, while the interim government's weak control over the situation in the south and its improper measures were undeniable at fault for the spread of the conflict.

Firstly, the Kyrgyz and Uzbek ethnic groups originally did not have many grievances. In the former Soviet Union, there had been some disputes between them due to the issue of national delimitation and pertinent interests, but the ethnic relations were generally harmonious. Although the Osh event in 1990 once caused tension in the ethnic relations, after the independence of the Central Asian countries, ethnic conflicts have eased, and intermarriage between ethnic groups was not uncommon. It can be said that the historical grievances of Kyrgyz and Uzbek ethnic groups had a certain impact on the outbreak of «June incident», but they were not the main reason for it.

Kyrgyzstan is a multi-ethnic country with close to 80 ethnic groups, of which the Kyrgyz is the main ethnic group. According to data released by the Kyrgyz National Statistical Commission in 2009 (2009, p. 52), the population of Kyrgyzstan has reached 5,363 million, of which Kyrgyz population reached 3,805 million and the Uzbek population reached 0,768 million, accounting for $70.9 \%$ and $14,3 \%$ of the total population, respectively. More than $90 \%$ of Uzbeks in Kyrgyzstan live in the southern part of the country. The population distribution in the south of the country is as follows: in Osh Region Kyrgyz account for $68.6 \%$, Uzbeks - 28\%; in Osh city, Kyrgyz account for 47.9\%, Uzbeks - 44.2\%; in Jalalabad Region, Kyrgyz account for $71.7 \%$, Uzbeks $-24.8 \%$ of the population (Ferghana News Agency 2011).

Kyrgyz and Uzbeks are the two most populous nationalities in Kyrgyzstan. Although there are differences in ethnic characteristics, there are not many grievances in history. Uzbeks as farming people are mainly living in southern Kyrgyzstan such as Osh, Osh Region and Jalalabad Region, where they have been the inhabitants and been deeply influenced by Islam since the 8th century. Kyrgyz people, as nomads, entered this area later. They first believed in Shamanism, and began to convert to Islam in the 16th century. The influence of Islam over Kyrgyz was relatively small. After the imperial Russia conquered Central Asia, the Kyrgyz people were more influenced by Russian culture in pursuing the Russification policy in Central Asia. Before the Russian conquest of Central Asia, the three khanates in the south of Central Asia - Khanate of Khiva, Khanate of Bukhara and Khanate of Kokand - Kingdom-both dynasties founded with Uzbeks as the main body. At that time, the status of Kyrgyz people was much lower than Uzbeks in both political, economic, and religious spheres. However, a relatively similar cultural tradition and national psychology formed between the two ethnic groups throughout this long history. In addition, since the ethnic con- 
sciousness of the Kyrgyz and Uzbek ethnic groups was not yet awakened, although there were political, economic, and cultural contradictions between them, their conflicts appeared more between different tribes than between the Kyrgyz and Uzbek ethnic groups (Yiqiang 2010).

After the October Revolution, the Soviet government began to do ethnicterritorial division in Central Asia, on basis of which it established five national republics - the Kazakh Autonomous Soviet Republic, the Uzbek Soviet Republic, the Kyrgyz National Autonomous Prefecture (upgraded to a Republic in 1926), The Turkmen Soviet Republic and Tajik Soviet Autonomous Republic. This measure has played a very important role in awakening the national consciousness of various ethnic groups in Central Asia and strengthening their national belonging. However, due to the historical intertwined state of various ethnic groups, it was difficult to determine the borders of the autonomous regions of any given nation, causing many border issues. One prominent issue was the transfer of the relatively concentrated Uzbeks city of Osh into the Kyrgyz Republic. The Uzbeks strongly opposed it at the time, saying that Osh was traditionally a hometown for Uzbeks and it was not right for the government to give their home to the Kyrgyz people. In Soviet Union, this dissatisfaction was quickly quieted publically without causing serious consequences, but the problem has persisted. Since ethnicterritorial division in 1924, Uzbeks in southern Kyrgyzstan had demanded that the city of Osh be transferred to the Uzbek Soviet Republic and occasionally had been on a collision course with local Kyrgyz.

On June 4 1990, an incident, namely the Osh event, in the southern part of the Kyrgyz Union Republic shocked the entire Soviet Union. Its cause was simple: Uzbeks and Kyrgyz people fought for construction land, initially in and around Osh, and then Uzgen, but the unrest then quickly spread to other cities. A large number of Kyrgyz and Uzbeks were involved in the conflict in Uzgen, Jalalabad and Osh. Even now, there is no detailed official information about this event. According to the Ministry of Internal Affairs of the Kyrgyz SSR and the Ministry of Internal Affairs of the former USSR, 305 people died and 1371 people were injured during the riots of 1990 (Rakhimov 2015). At that time, the Central Government of the Soviet Union sent troops to control the incident by force (at that time, more than 20,000 Uzbeks of Uzbek SSR tried to get to Osh to reinforce their compatriots, but were forcibly prevented from doing so). There were still serious repercussions. After this incident, the migration of young Kyrgyz and Uzbeks to neighbourhoods, villages and towns with relatively concentrated opposing ethnic populations has worsened the ethnic relationship between Kyrgyz and Uzbek ethnic groups. It should be noted, this incident was not caused by the intensification of ethnic conflicts, but by socio-economic problems. The inaction of the government of the Kyrgyz SSR at that time was an important cause of the spread of the conflict (Ferghana News Agency 2011). After the Central Asian countries gained independence, ethnic conflicts between Kyrgyz and Uzbeks have eased, and intermarriages between them became quite common. 
Secondly, the policy of «kyrgyz first» adopted after the independence of Kyrgyzstan exacerbated the conflict of interests of the Kyrgyz and Uzbek ethnic groups, which also affected the harmony of relations between Kyrgyzstan and Uzbekistan, and the relations between the two countries in turn deteriorated. This has further stimulated the worsening of ethnic relations between the Kyrgyz and Uzbek ethnic groups within the Kyrgyz Republic.

After Kyrgyzstan achieved independence, when the nation-state was being constructed, Kyrgyz people's status and dominance were continuously strengthened through political, economic, cultural and other policies, while the interests of Uzbek, Russian and other peoples were supressed to varying degrees. This caused strong dissatisfaction from non-dominant peoples. Many Russians moved out of Kyrgyzstan, which caused the loss of a large number of technical talents. It was a serious blow to the socio-economic development of Kyrgyzstan. Russians and other European nations (Ukrainians, Belarussians, Germans) moved out, leaving positions vacant in some regions and industries in Kyrgyzstan.

In terms of language and culture, the constitution of Kyrgyzstan not only stipulates that Kyrgyz is the national language, but also that only persons who are proficient in the national language are eligible to participate in the presidential election. The Uzbeks have been asking the government to set the Uzbek language as the official language and protect their cultural traditions and rights to live and work, but their requirements have not been fully met.

In terms of politics, the Kyrgyz President, Prime Minister, Speakers of both Houses of Parliament, and leaders of important national positions such as the Minister of Foreign Affairs and Minister of Defence are all Kyrgyz people. In February 1995, the first two rounds of the Kyrgyz Parliament were elected. Of the 78 members, the Kyrgyz people accounted for nearly 90\% (while the Kyrgyz people accounted for only $52.4 \%$ of the total population of the country) (The Research Office of the United Front Work Department 2010). The level of Uzbek representation in central and local authorities does not match their actual numbers. Uzbeks have the lowest percentage of officials in the military, security agencies, internal affairs departments, tax authorities, financial departments, prosecutors and judicial departments (Ferghana News Agency 2011). After the establishment of the interim government in 2010, an Uzbek leader stated that Uzbeks would win 10 seats in the Kyrgyz parliament, but the interim government quickly appointed pro-government Kyrgyz to be the governors of Osh and Jalalabad regions, which led to strong dissatisfaction from local Uzbeks.

The economic development of Kyrgyzstan is unbalanced, especially in terms of North and South. The economic level of the North is higher than that of the South, while the industry gap is also very prominent. From a countrywide perspective, the northern region where the Kyrgyz majority is concentrated is more developed. Bishkek (No.1 capital) has been the economic and cultural centre since the days of the Soviet Union, and Kyrgyzstan's industrial areas are mostly located in the north. The south is mainly dominated by agriculture and 
animal husbandry. In terms of industry differences, the Uzbeks are mainly engaged in catering, hotels, transportation, communications, construction, trade, and textile, but most of them are in the status of entrepreneurs, while Kyrgyz people have an advantage in national government agencies, law enforcement agencies and security agencies. In recent years, with the development of urbanization in Kyrgyzstan, a large number of farmers have moved to cities to work, which has increased the competition on the labour market. This is a normal problem in the process of social and economic development, but it is manifested in the form of ethnic conflicts. In addition, Kyrgyz government agencies have serious corruption problems. According to Transparency International at the end of 2009, Kyrgyzstan ranked 162 out of 180 countries in this regard (Transparency International 2009, p. 12). This shows that the level of corruption is dire. Uzbeks in the business and trade sectors are often targeted by government officials for extortion. Their economic rights and interests are not effectively protected by the government, which makes them very dissatisfied with it.

After the Central Asian countries gained independence, the border issues and water allocation issues leftover from the Soviet Union's delimitation became important obstacles affecting the relationship between Kyrgyzstan and Uzbekistan. From time to time, these issues influenced the ethnic relations between the ethnic groups in the south of Kyrgyzstan. Uzbeks have always believed that the city of Osh should be placed under Uzbekistan. Uzbekistan's semi-officials and civilians repeatedly made territorial claims on Osh. In response, the Kyrgyz government declared Osh as its second capital in 2000. The Kyrgyz President and government also established local offices to strengthen the concept of Osh as a territory of Kyrgyzstan, while Uzbeks in the south of Kyrgyzstan ignored the orders and regulations of Kyrgyz government with the backing of the geographically adjacent Uzbekistan. Osh and Jalalabad Regions were almost half out of control, especially when obstacles occurred between Uzbekistan and Kyrgyzstan. In addition, Kyrgyzstan and Uzbekistan have problems with the distribution of water resources from the Syr Darya. Kyrgyzstan is north of the major river Syr Darya. They use water resources mainly for power generation and the peak of water consumption is in winter. Meanwhile, the downstream Uzbekistan use water mainly for irrigation, and the period of peak water use is in spring and summer. The most serious confrontation happened in the spring of 2000. At that time, Uzbekistan organized military exercises near the border and stated that the goal of the exercise was to seize the dam. In response, Kyrgyzstan released an announcement saying that if Uzbekistan were to start the exercises, Kyrgyzstan would blow up the dam and plunge Uzbekistan into a flood. Although the two sides did not really do it, this posturing reflected the tension between them. It is natural that the relationship between the two countries directly affects the relationship between the two nationalities in the two countries. The dispute between the two countries caused the contradictions between Uzbeks and Kyrgyz in Kyrgyzstan to widen, but the same could be observed in Uzbekistan. 
Finally, the «April Incident» in 2010 led to the outbreak of unrest in Kyrgyzstan. The interim government's control of the South was greatly weakened. Organized criminal groups and extremists took the opportunity to provoke ethnic conflicts, directly leading to the rapid spread of ethnic conflicts in the South and increasing the local tension and the intensity of ethnic conflicts. The inaction of the interim government is also one of the important reasons for the expansion of the «June incident».

After the coup on April 7, 2010, Bakiyev and his supporters took action against the interim government in the south. Former President Bakiyev is from the south and thus had many supporters there, both Kyrgyz and Uzbeks. They jointly opposed the interim government. On May 13, Bakiyev supporters, some of whom were armed, occupied government buildings in Osh, Jalalabad and Batken regions. The Kyrgyz interim government accused Bakiyev's youngest son, Maxim of providing $\$ 30$ million to Bakiyev's supporters in an attempt to use ethnic conflicts to create chaos and put pressure on the interim government, but the Kyrgyz government did not provide specific examples. The report of the "Osh Initiative» even argues that the June incident was approved and planned by individual Kyrgyz politicians, the leaders of the country's organized criminal groups and supporters of former President Bakiyev (Osh Initiative 2011, p. 58). It is doubtful whether this ethnic conflict was provoked by Bakiyev. It might have even been the interim government that wanted to divide and split Bakiyev's supporters by means of ethnic conflict. According to the report of the "Osh Initiative", officials in the interim government made many irresponsible speeches before the beginning of the conflict, and witnesses to the conflict confirmed that police and soldiers in the southern region had participated in the conflict (Osh Initiative 2011, p. 9 and 13). Regardless of whether this ethnic conflict was provoked by Bakiyev or the interim government for political purposes, the objective result was the disruption of the social order in southern Kyrgyzstan.

According to the report of the "Osh Initiative», a large number of hired armed forces were found to have shot and killed civilians during the conflict. The killers included both Uzbek and Kyrgyz people. Their intention was obvious - to promote ethnic conflicts and profit from the situation. It is still difficult to judge who hired these men or what their true identity was. However, some signs suggest and many analysts believe that drug trafficking groups and extremists in southern Kyrgyzstan are likely to have been involved. The "Osh Initiative» report states that the ethnic conflict was carried out by individual bottom-level individuals from the country's remote and poor areas in conjunction with members of Kyrgyz law enforcement agencies, the armed forces and organized crime groups (Osh Initiative 2011, p. 58). Osh is an important drug distribution centre in Central Asia. A large number of Afghan drugs enter Kazakhstan, Russia and Europe through Osh. Some media reports have theorised that the Bakiyev regime controlled the drug trafficking groups to a certain extent and profited from them. After Bakiyev's departure, the drug groups that still supported Bakiyev participated in the attack on the new regime and ethnic conflicts in the south. Due to the signifi- 
cant funds and weapons of the drug groups, their ability to participate was much larger than others' were. It is difficult to make a more accurate analysis and evaluation of this factor due to the lack of further information.

The Kyrgyz interim government can also undoubtedly be held responsible for the «June incident». Objectively speaking, the interim government had just been established and had insufficient control over the south at that time. This provided an opportunity for extremists and organized criminal groups such as drug trafficking syndicates in the south. However, this does not take the responsibility off the interim government completely. In an area where ethnic relations are fragile and sensitive, such as Osh, any mistakes in governing, even accidental ones, can cause explosive conflicts. In late May 2010, OSCE formulated a strategy for preventing ethnic conflicts based on the signs of instability that had already appeared in southern Kyrgyzstan and held meetings in Bishkek and Osh, including officials and various community representatives, to communicate and coordinate in order to prevent the conflict. OSCE recommended the interim government to take measures as soon as possible to prevent further deterioration of inter-ethnic relations and conflicts. However, the recommendations of the OSCE did not provoke any reaction from the interim government, who did not take any corresponding measures. In addition, law enforcement agencies such as the police in south failed to take decisive steps to stop the turmoil in the immediate aftermath of the conflict, letting it spread. The «Osh Initiative» has even accused Kyrgyz security forces of participating in the conflict.

\section{Impact of ethnic conflict in southern Kyrgyzstan}

The results of the two investigations quite differ concerning the development, specific causes, perpetrators, responsible persons, casualties, and economic losses of this ethnic conflict in Kyrgyzstan. According to the limited materials currently available, it is still difficult for the author to make a comprehensive and meticulous analysis of this ethnic conflict. However, the adverse impact caused by this ethnic conflict is relatively clear. It not only created huge negative consequences for the ethnic relations and social stability of Kyrgyzstan, but also affected the security situation and counter-terrorism in Central Asia. At the same time, the conflict has also initiated reflection from the governments of Kyrgyzstan and Uzbekistan.

Firstly, Kyrgyzstan is a direct victim of this ethnic conflict. Its domestic ethnic relations and social stability have deteriorated as a result, and the relations between Kyrgyzstan and neighbouring countries have been adversely affected. This conflict will further exacerbate the hatred between the Kyrgyz and Uzbek 
ethnic groups, and this hatred will be difficult to eliminate in the short term. Due to the greater casualties and economic losses of the Uzbeks in this conflict, more Uzbeks may be pushed into the arms of «Islamic Movement of Uzbekistan» and «Hizb ut-Tahrir» and thus further strengthen the power of terrorist organizations, which will be a serious challenge for the Kyrgyz government to face. This conflict will also give the Kyrgyz government less space for manoeuvers when dealing with national ethnic issues, as even a slight inadvertence may trigger new ethnic conflicts. In addition, a large number of refugees who left their homes during the conflict will become domestic or international refugees. How to properly settle these refugees at home and abroad, especially the return of refugees who were exiled abroad during the turmoil, is also a key issue that the Kyrgyz government has to face.

Transnational refugees who fled during the Kyrgyz unrest also adversely affected Kyrgyzstan's relations with its neighbours. Kyrgyzstan has four neighbours: Uzbekistan, Kazakhstan, Tajikistan and China. When the conflict broke out, there had already been tension between Kyrgyzstan and Uzbekistan due to unresolved territorial disputes and water disputes. This ethnic conflict undoubtedly worsened their relationship. The relationship between Kyrgyzstan and Tajikistan has always been lukewarm. Kyrgyzstan's relations with Kazakhstan had been closer, but also cooled down after the «April Incident».

Secondly, this ethnic conflict has caused a large number of casualties and damages, which have adversely affected the economic development of Kyrgyzstan, and the economic gap between North and South has continued to widen. Kyrgyzstan is a poor mountain country. In the early days of its independence, the Kyrgyz government introduced the market economy ambitiously, but it is difficult for its economy to transition because of long-standing use of the planned economy model. This also contributed to the growing economic gap between the North and the South and the increasingly prominent ethnic confrontations. The change of the regime in 2010, especially the ethnic conflict that took place in June, caused the GDP for that year to shrink by $0.5 \%$, fiscal deficit to rise to $11 \%$ of GDP (The World Factbook 2014). In the south, agricultural production, infrastructure and trade activities have been severely damaged.

Thirdly, a large number of merchants, arms and ammunition businesses in southern Kyrgyzstan were looted during the conflict. If these funds and weapons have fallen into the «IMU», «East Turkistan Islamic Movement», «Hizb ut-Tahrir» and other «three forces», the security situation and counter-terrorism situation in Central Asia, including the Fergana Valley will be inevitably impacted. Roza Otunbayeva noted in her interview that 3,000 weapons from an arsenal were snatched in a small place «Miley-Sai»(to the north of Jalalabad) (Amanaliev 2010). There have been many such cases. In addition, a large number of armed violent insurgents were trained during this conflict. Later, a considerable number of these people joined the «Islamic State». Their return will threaten Kyrgyzstan and the entire Central Asia region. 
Finally, this ethnic conflict puts the governments of Kyrgyzstan and Uzbekistan on the task of improving the relationship between the two countries and the relations between Kyrgyz and Uzbeks. During the time of Atambayev, the government of Kyrgyzstan began to take measures aimed at improving the relations between these two ethnic groups, but due to the freshness of the conflict the southern population was still in grief - the effect was not obvious and the two major ethnic groups maintained a considerable distance. The relations between two countries and between two major ethnic groups in Kyrgyzstan improved markedly only after Cooronbay Jeenbekov and Shavkat Mirziyoyev became presidents respectively in October 2017 and December 2016.

Jeenbekov's emphasis on the economic development of southern Kyrgyzstan and his punishment for inciting ethnic conflicts and distributing conflict videos has achieved good results. For the occasion of the eighth anniversary of the ethnic conflict in 2018, he published a letter to the people of the country, which stated, "the tragedy of June 2010 should be a huge lesson for all of us" (Ferghana News Agency 2018). After taking office as president, Mirziyoyev made the development of friendly relations with neighbours in Central Asia a priority in foreign policy. Uzbekistan-Kyrgyzstan relationship is an important part of this. With the joint efforts of these two presidents, the two countries launched joint military manoeuvres on the border, signed a border treaty based on the principles of good neighbourliness, mutual respect and recognition of the interests of both parties (Larin 2019). With the settlement of the border issue between these two countries and the increase in mutual trust, the relationship between Kyrgyz and Uzbeks in southern Kyrgyzstan has improved, but the complete resolution of hatred requires not only a certain amount of time, but also the joint efforts of the governments of Kyrgyzstan and Uzbekistan.

\section{Conclusions}

From the above analysis, the following conclusions can be drawn.

First of all, the ethnic conflict that occurred in southern Kyrgyzstan ten years ago has had political ramifications. The irregular regime change in April 2010 created the conditions for the outbreak of this conflict in the south and it was not conducive to the rapid and effective handling of the conflict by the interim government. This resulted in the escalation of conflict. That is, the April 2010 and June 2010 events are contextually related.

Second, three major factors have led to the occurrence and spread of the ethnic conflict in southern Kyrgyzstan. The first factor is the impact of the former Soviet ethnic policy and the historical grievances between Kyrgyz and Uzbeks. The second factor is «Kyrgyz priority» policy, which exacerbated the conflicts of 
real interest between two major ethnic groups in southern Kyrgyzstan and deteriorated the relations between Kyrgyzstan and Uzbekistan. The third is the inaction of the interim government and the involvement of organized criminal groups and extremists.

Third, this ethnic conflict has adversely affected Kyrgyzstan's development, the security and anti-terrorism situation in Central Asia. It has greatly affected not only the national relations, social stability and economic development in Kyrgyzstan, but also the Kyrgyzstan's relations with neighbouring countries. At the same time, the arms looting and the intervention of terrorist forces during the conflict have already threatened the security situation in Central Asia.

Finally, this ethnic conflict has forced the governments of Kyrgyzstan and Uzbekistan to attach greater importance to the relationship between themselves and the two major ethnic groups. With the efforts of presidents Jeenbekov and Mirziyoyev, the political mutual trust between these two countries has clearly increased and their territorial border issue has been resolved smoothly, which has provided good external conditions for the improvement of the relationship between the two major ethnic groups in southern Kyrgyzstan. At the same time, since many people in southern Kyrgyzstan have been deeply affected by this ethnic conflict, the commemorative and reflective activities have begun among the people, which will help to narrow the relationship between Kyrgyz and Uzbeks in Kyrgyzstan.

\section{References}

1. Amanaliev A. (2010). Weapons from Tajikistan are being delivered to the south of Kyrgyzstan. Authorities do not react. Retrieved from: http://www.pr.kg/news/kg/2010/09/08/17218/

2. Ferghana News Agency. (2011). Conclusion of the National Commission on the tragic events that occurred in the south of the republic in June 2010. Retrieved from: https://www.fergananews.com/article.php?id=6871;

3. Ferghana News Agency. (2011). Information from the independent commission of the Ombudsman (Akyikatchy) of the Kyrgyz Republic on the tragic June events of 2010 that took place in Osh, Jalal-Abad regions and the city of Osh. Retrieved from: http://news.fergananews.com/archive/ 2011/akuna.html;

4. Ferghana News Agency. (2011). Report on the work of the temporary parliamentary commission of the Jogorku Kenesh of the Kyrgyz Republic to identify and investigate the circumstances and conditions that led to the tragic events that occurred in the republic in April-June 2010, and to give them a political assessment. Retrieved from: http://news.fergananews.com/ photos/2011/06/otchetMamytov.doc; 
5. Ferghana News Agency. (2018). Jeenbekov urged Kyrgyz people to learn from the Iziyun tragedy of 2010. Retrieved from: https://www.fergananews.com/ news.php?id=30440

6. Freedom House, Memorial Human Rights Center, Norwegian Helsinki Committee. (2012). A chronicle of violence. The events in the south of Kyrgyzstan in June 2010 (Osh Region). Report № 2. Retrieved from: https://www.fergananews.com/news/photos/2013/06/774.pdf.

7. Human Rights Watch. (2010). Where is the Justice? Interethnic Violence in Southern Kyrgyzstan and its Aftermath. Retrieved from: http://www.hrw.org/ sites/default/files/reports/kyr gyzstan0810webwcover_1.pdf

8. International Crisis Group. (2010). The Pogroms in Kyrgyzstan. Retrieved from: http://www.crisisgroup.org/ /media/Files/asia/centralasia/kyrgyzstan/ 193\%20The\%20Pogroms\%20in\%20Kyrgyzstan.pdf

9. Larin I. (2019). Two tactics of border existence in Central Asia. Rhythm of Eurasia. Retrieved from: https://www.ritmeurasia.org/news--2019-10-18--dvetaktiki-pogranichnogo-bytija-v-centralnoj-azii-45476

10. National Statistical Committee of the Kyrgyz Republic. (2009). Population and Housing Census of the Kyrgyz Republic of 2009, Bishkek.

11. Osh Initiative. (2011). Report on the Results of the Independent Public Investigation into June (2010) Events in Kyrgyzstan. Retrieved from: http://news.fergananews. com/archive/2011/oshini.doc

12. Rakhimov, I. (2015). Osh events of 1990 in Kyrgyzstan. RIA News. Retrieved from: https://ria.ru/20150604/1067754280.html

13. The Research Office of the United Front Work Department of the Central Committee of the People's Republic of China. (2010). Enlightenment of Kyrgyzstan's Unrest Caused by Ethnic Problems on China's National Work. Journal of Chongqing Institute of Socialism, No. 6.

14. Sputnik news. (2015). Kyrgyzstan remembers the casualties of 2010 revolution. Retrieved from: https://tj.sputniknews.ru/asia/20150407/1015083492.html

15. Transparency International. (2009). Corruption Perceptions Index 2009. Retrieved from: https://www.transparency.org/en/cpi/2009\#

16. The World Factbook. (2014). Kyrgyzstan. Retrieved from: https://cia_world_ factbook_2014.enacademic.com/131/Kyrgyzstan.

17. Yiqiang, J. (2010). Impact analysis of tribal factors in Kirghizstan political transition [J]. Russian, Central Asian \& East European Studies, No. 9. 